\title{
RESPONSE TO THE EDITORIAL "PSYCHO-EMOTIONAL CARE IN A NEONATAL UNIT DURING THE COVID-19 PANDEMIC"
}

\section{Resposta ao editorial "Cuidados psicoafetivos em unidade neonatal diante da pandemia de COVID-19"}

Cristiane Ajnamei dos Santos Alfaya ${ }^{*}$

Dear Authors,

The Editorial of Revista Paulista de Pediatria entitled "Psychoemotional care in a neonatal unit during the COVID-19 pandemic" contributes to a deep reflection on maternal and child mental health. Based on Winnicott's theoretical concepts, which are described in this text, the important discussion on the "caring" topic continues, especially in the current context of the COVID-19 pandemic. $^{1}$

Overall, the act of caring brings with it a burden of responsibility that can lead to feelings and experiences of physical, psychological, social, and institutional exhaustion. In institutional spaces where health is taken care in order to promote well-being and healing, especially of the baby in a neonatal unit, it is necessary to consider both the baby's period of development and the state of emotional availability that the healthcare team can offer to promote the socio-affective development of children and their family.

From the perspective of the initial maturational processes, according to Winnicott's psychoanalytic theory, the individual's mental health comprises three main aspects: the state of "going-on-being" that, according to the author, has a continuous potential; the sense of "feeling real," that is, one's feeling of existing and living in the body itself; and one's sense of genuinely "doing," through creativity and with autonomy. In order for these processes to achieve the development of the true self, that is, the "being" and the "doing" with creativity and autonomy, Winnicott postulated that, during the last months of pregnancy and the first weeks after childbirth, the mother experiences a special psychological state called "primary maternal preoccupation." This state of increased sensitivity, which women experience in the pregnancy-puerperium period, allows the mother to meet the baby's needs through projective identification. Thus, the mother's past experiences as a daughter, her expectations as the baby's parent, as well as the mother's expectations and experiences with her own mother (the baby's grandmother), can be observed in the mother's interaction with the baby in the present. Therefore, the current mother-baby interaction involves the objective and subjective aspects of past and present interactions (expectations and experiences) in addition to the different contexts and current social conditions in which the mother-baby dyad is inserted. During the pregnancy-puerperium period, according to Winnicott, women experience a partial regression of the ego in order to identify with the baby and meet the child's needs. Hence, it is paramount that the mother experiences a good enough environment ("holding") in the present, in such a way to perform the function of caring for her baby with the predominance of current and positive subjective experiences. ${ }^{2,3}$

In the current context of the COVID-19 pandemic, the neonatal intensive care unit, together with healthcare professionals, has been performing the aforementioned functions, which are deemed essential to promote the baby's physical and psychological maturational processes. Winnicott highlights the maturational processes as linked to the concept of holding, which involves the experience of physical protection due to the baby's skin sensitivity - touch, temperature - as well as its auditory, visual, and touch sensitivity. This is also because the baby is still unaware of its full existence (fragments of the ego or subjective experiences) as well as everything other than itself (external environment). In this sense, the aim of the initial period of human development is the integration of subjective experiences (pulsion, instincts, perceptual and motor capacities) to form the core of the self (ego) and personalization - to acquire the sense that the body houses the true self. Moreover, according to this theorist, holding 
involves the routine of physical care for the baby throughout the day and night as well as expressing love and affection with the physical contact of holding the child in one's arms. The environment provided by holding (mother/parents, primary caregiver, or healthcare professional) works as an auxiliary ego, being a determining factor in the transition from the state of non-integration (baby's absolute dependence) to that of integration (from relative dependence to independence). These states can be later observed in children's exploratory behavior, in their creativity, autonomy, initiative, attention, among others, during the act of playing. The individuals' continuous process of going-on-being through subjective experiences in the interaction with the environment (mother/parents, primary caregiver, or healthcare professional) will form the basis for the development of the individuals' healthy potential toward autonomy and independence such as senses of trust, belonging, self-esteem, safety, emotional regulation, among others. ${ }^{4}$

Winnicott highlights the processes of emotional maturation as being innate to the individual toward life, that is, to the encounter of internal (I) and external (other) objects. The baby's opportunity to find these objects, due to the subjective experiences resulting from interactions with the environment, allows individuals to construct senses and meanings about themselves and the other (world). Therefore, holding (good enough environment), which reflects the image of oneself and that of the other, initially merged and undifferentiated, allows for the separation and true differentiation of real objects through interactive exchanges and subjective experiences of the self. ${ }^{2,3,4}$

Integration is achieved by two types of experiences: on the one hand, the mother's support, who "collects the little fragments of the ego," is especially important, enabling the child to feel integrated with her; on the other hand, there is a type of experience that tends to bring personality together in an internal base (the baby's mental activity). There comes a time when children, thanks to the aforementioned experiences, manage to bring together the cores of their ego, having the notion that they are different from the world surrounding them. This moment of differentiation between "me" and "not me" can be dangerous for the baby, as the outside can be perceived as agonizing and threatening. These threats are neutralized, in a healthy development, by the existence of loving care on the part of the mother. The true self begins to have life through the strength given to the infant's weak ego by the mother, when implementing the child's omnipotence expressions. Again, the role of the environment (mother/parents, primary caregiver, healthcare professional) is to provide the baby with an auxiliary ego that allows it to integrate its bodily sensations, environmental stimuli, and motor skills. Otherwise, babies may replace the protection they lacks with one "made" by them, wrapping themselves in a shell at the expense of which the false self grows and develops. Individuals develop as an extension of the shell, an extension of the environment that is not good enough, threatening and hostile, which has failed to interpret their needs, being unable to implement the infant omnipotence and imposing the infant gesture. The false self, especially when it is at the most pathological extreme of the scale, is usually accompanied by a subjective feeling of emptiness, futility, and unreality. ${ }^{5}$

Winnicott defines personalization as "someone's feeling of being in their own body." The author suggests that normal development would lead individuals to achieve a body scheme, a psyche-soma unit, as called by Winnicott, which forms their body scheme as a whole - it is interpenetrated and developed in a dialectical relationship and presents the diversity paradox in the unity. As development progresses, children have a relatively integrated ego and the feeling that their own core inhabits their body. Children and the world are two separate things. The next step is to achieve the adaptation to reality. At this stage, the parents, primary caregiver, healthcare professionals have the function of providing children with the elements of reality with which they will be able to create their psychic image and that of the outside world. ${ }^{5}$

In this sense, intervention strategies in the routine of care in neonatal units aimed at the newborn, at the family, as well as those aimed at the caregiver described by the authors Denise Streit Morsch, Zaira Aparecida de Oliveira Custódio, and Zeni Carvalho Lamy in the Editorial of Revista Paulista de Pediatria, are essential for promoting physical, psychological, social, and institutional health in the bidirectional relationship established between families with babies in intensive care units and healthcare professionals working in such units.

\section{REFERENCES}

1. Morsch DS, Custódio ZA, Lamy ZC. Cuidados psicoafetivos em unidade neonatal diante da pandemia de COVID19. Rev Paul Pediatr. 2020;38:e2018277. http://dx.doi. org/10.1590/1984-0462/2020/38/2020119

2. Winnicott DW. Da pediatria a psicanálise. Rio de Janeiro: Imago; 2000.
3. Winnicott DW. O ambiente e os processos de maturação. Poro Alegre: ArtMed; 1983.

4. Winnicott DW. O brincar e a realidade. Rio de Janeiro: Imago; 1975.

5. Winnicott DW. Tudo começa em casa. $3^{a}$ ed. São Paulo: Martins Fontes; 1999. 


\section{RESPONSE LETTER Carta-resposta}

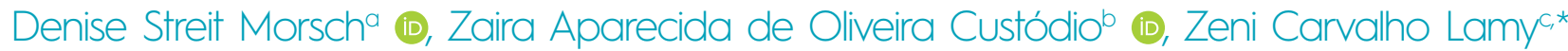

Dear Prof. Cristiane Ajnamei dos Santos Alfaya,

It was a great pleasure to receive your comments on the editorial we wrote about neonatal care in the context of the COVID-19 pandemic, ${ }^{1}$ not only for stimulating our work, but also for giving us the opportunity to discuss issues we deem fundamental in humanized care for the newborn - the Kangaroo-Mother Care Method.

Since the beginning of the formulation of this health policy, implemented by the Brazilian Unified Health System, a fruitful path of seeking and integrating knowledge from different fields - biological, psychological, and social - involved us all, national consultants. In our daily practice in neonatal units, we recognize newborns as subjects who, despite their size and age, demand the presence of their parents, especially their mothers, for true survival as a person in addition to physical survival.

Among theories that guided the assumptions of our work, a special attention was given to the Winnicottian theory, particularly concerning primary maternal care. And you preciously explain the importance this theory had in supporting our intentions. We are grateful to Winnicott, who allowed us to assess the importance of holding, of the primary maternal preoccupation, of the differentials proposed by maternal care and spontaneous gesture. But, as he himself proposes in his book Human Nature, "understanding of the human child is deficient if it stops short at the limits of the infant tasks and needs." 2 Thus, we seek to discover the measures indicated by him, starting with the importance of the team in proposing a rightful place for the parents and family of these babies.

Furthermore, we seek to offer neonatal professionals the knowledge that, in addition to skin-to-skin contact, understanding what the baby and its family are going through in this situation is paramount. The objective has always been to provide the best care and management in the face of the various occurrences and complications that are part of the routine of a neonatal unit. We were aware that space and time lead to an intense differentiation from the original script, which is so particular to full-term birth. This is because the small babies we received each day, of different gestational ages, some very preterm, offered our practice significant and specific demands, such as this, which reminds us that maternal sensitivity must be facilitated to the baby:

What the mother needs is the chance of being natural and finding her way with the baby, just as other mothers have found their own ways since the dawn of human history, and even before the evolution of man from the mammals. ${ }^{2}$

There were, however, concrete issues that required us to broaden our observations. How to facilitate the presence of the woman/ mother with the baby? We have, for both the mother and the baby, a time that has not been completed, in which basic experiences of the gestational and even fetal period could not occur due to the anticipation of childbirth. There is a different time and space in neonatal units, unexpected, unwanted and, in most cases, unknown to the family of this child who is under our care. Perhaps the only people who are in a space and time that meet a desire, a choice, a specific will to care, are the healthcare professionals.

In his few references to preterm birth, we find in the same aforementioned book:

At some point close to childbirth, a great awakening occurs, responsible for the noticeable difference between a baby prematurely born and another with a postmature birth. The first is not yet ready for life, and the second is subject to being born in a state of frustration for being kept waiting after being ready.

*Corresponding author. E-mail: zenilamy@gmail.com (Z.C. Lamy).

aNational Consultant in the Kangaroo-Mother Care Method, Ministério da Saúde, Brasília, DF, Brazil.

bUniversity Hospital, Universidade Federal de Santa Catarina, Florianópolis, SC, Brazil.

'Department of Public Health, Universidade Federal do Maranhão, São Luís, MA, Brazil.

Received on December 14, 2020. 
In other words, although Winnicott does not advance the theoretical questions of preterm birth, the author marks the difference of this birth and indicates the need to better know who "would not be ready for life." We had to know the baby's evolutionary moment, its capacities and competences and, therefore, we resort to other authors.

The way of touching and bringing the role of words closer to the incubators also led to the concern with healthcare professionals, who are so emotionally required in these care practices, and also with the ambience understood as the environment surrounding the baby and its therapeutic function in caring. ${ }^{3}$ Gradually, all these concerns became clues to the understanding that we should try the holding of holding itself. We took the liberty of resorting to Winnicott and so many other theorists so we could try to adapt to their special contributions, new approaches in the space of neonatal care units.
Nevertheless, we must remember that in these paradigms the skin-to-skin contact provided by the kangaroo position occupies a special place in the physical and psychological care of our babies. We believe that, in this practice, Winnicott's proposals become the major care initiative. It is in the skinto-skin contact, provided by the kangaroo position, that continuity takes place. We have never intended to say that this is a return of the baby to an intrauterine period. Babies know they were born, but they need to have experiences in which these anticipated changes do not necessarily lead to disruptions, which would be very detrimental to their development. Upon finding their mothers' body again, available to continue a closeness in which holding and handling constitute a special scenario for this encounter, preterm babies can relax their body, so requested by clinical, sensory, and psychic demands of their prematurity.

\section{REFERENCES}

1. Morsch DS, Custódio ZA, Lamy ZC. Cuidados psicoafetivos em unidade neonatal diante da pandemia de COVID19. Rev Paul Pediatr. 2020;38:e2018277. http://dx.doi. org/10.1590/1984-0462/2020/38/2020119

2. Winnicott DW. Natureza humana. Rio de Janeiro: Imago; 1990.
3. Brazil - Ministério da Saúde. Secretaria de Atenção à Saúde. Departamento de Ações Programáticas e Estratégicas. Atenção Humanizada ao Recém-Nascido: Método Canguru. $3^{a}$ ed. Brasília: Ministério da Saúde; 2017. 340p. (Manual Técnico). 